\title{
The Development Instrument Test of PISA and Student Worksheet (LKPD) with Shape and Space Content Using RME Approach to Improve the Mathematic Representation Ability of High School Students
}

\author{
Chrisna Sinaga*, KMS. Amin Fauzi, Izwita Dewi \\ Mathematics Education Postgraduate Program, State University of Medan, Medan, Indonesia \\ *Corresponding author: chrisna3sinaga@gmail.com
}

Received October 12, 2019; Revised November 28, 2019; Accepted December 22, 2019

\begin{abstract}
The purpose of this study was to produce Student Worksheet (Lembar Kerja Peserta Didik / LKPD) and PISA-based test instruments that were valid, practical, effective and able to improve students mathematical representation abilities. This type of research was the Tessmer model development research. The trials in this study were conducted in class X-Science 3 and X-Science 4 of SMA Negeri 1 Dolok Batu Nanggar. From the results of trial I and trial II obtained: (1) LKPD and PISA-based test instruments on the developed RME model were valid and practical, but have not met effective criteria namely: a) classical student completeness of more than $85 \%$; b) achievement of learning objectives of more than $75 \%$ for each item; c) students who gave a positive response of more than $80 \%$; and d) achievement of learning time was the same as regular learning time; and (2) there was an increase in the average mathematical representation ability of students in the first trial was 0.4 with moderate and in the second trial was 0.6 in the medium category.
\end{abstract}

Keywords: student worksheets, test instruments, PISA, RME, mathematical representation ability

Cite This Article: Chrisna Sinaga, KMS. Amin Fauzi and Izwita Dewi, "The Development Instrument Test of Pisa and Student Worksheet (LKPD) with Shape and Space Content Using RME Approach to Improve the Mathematic Representation Ability of High School Students.” American Journal of Educational Research, vol. 7, no. 12 (2019): 957-965. doi: 10.12691/education-7-12-10.

\section{Introduction}

Mathematics is a universal science that underlies the development of modern technology [1]. Mathematics which has an important role in everyday life. Mathematics as a symbolic language implies that mathematics is universal and can be understood by everyone anytime and anywhere [2]. In order to create and mature modern technology in the future, strong basic mathematical skills are needed. The demand of students' ability in mathematics is not just the ability to count, but the ability to reason logically and critically in problem-solving.

[3] Five basic abilities according to NCTM that become standard mathematical abilities include: problem-solving, reasoning and proof, communication, connections, and representations. The ability of mathematical representation is the ability to translate mathematical problems or ideas by drawing, expressing, or modeling mathematically in an effort to find a solution to the problem at hand. Representation is central to the study of mathematics Students can develop and deepen their understanding of mathematical concepts and relationships as they create, compare and use various representations [3]. The ability of representation is very necessary for a person to be able to solve a problem or a new situation for him by linking the knowledge he has to the problem at hand.

A problem solving is a process of how knowledge is organized and represented symbolically in the long-term memory in order to be activated efficiently when problem solving occurs [4]. Successful problem solving is not possible without appropriate representation. Appropriate problem representation is the basis for understanding the problem and making a plan to solve the problem. Therefore the ability of mathematical representation is an inseparable part of problem-solving which is very instrumental in learning mathematics.

Characteristics of students in Indonesia in learning mathematics are generally skilled in solving routine problems, namely problems that can be solved directly using concepts or procedures that are already known or abilities that have been learned. However, students in Indonesia are weak in solving non-routine problems that are problems that are not commonly encountered by students and contain many cases for students to organize and consider.

This can be seen from the results of the PISA (Program for International Student Assessment) survey which states that the mathematical abilities of Indonesian students are relatively low. According to the OECD survey, 
Indonesia's achievements in PISA studies are far from satisfying. In 2003, Indonesia ranked 36 out of 41 countries. In 2012 it was ranked 63 out of 64 countries. The average Indonesian mathematics score was 375, whereas the average OECD score was 494 [5].

The low PISA test results of students in Indonesia because students are very rarely working on PISA-type questions in classroom learning. This also happened because of the unavailability of the PISA model in Indonesia. [6] Therefore, it is necessary to develop or create questions about the PISA model so that Indonesian students become accustomed to solving non-routine problems (contextual problems). [7] One way to help teachers implement PISA question-based learning, with the goal of getting students used is to provide a PISA question bank. Providing assistance/ scaffolding in learning mathematics needs to be given to students, one of them is by providing student worksheets [8]. Scaffolding functions to guide students in the learning process and encourage students to become independent learners while collaborating with their group members. Scaffolding is giving the student a more active role in their learning as opposed to teacher directed learning (giving students answers without letting them work it out for themselves) [9].

The ability of mathematical representation is useful for students in an effort to provide understanding and illustration in communicating the solution to a given problem. Representation is very instrumental in helping to increase students' understanding of mathematical concepts stated that representation can be used to understand mathematics. Mathematics requires representations because of the abstract nature of mathematics such that people have access to mathematical ideas only through the representation of those ideas [10]. One suitable learning model to help students improve their mathematical representation ability is the RME (Realistic Mathematics Education) approach. In the RME approach students are faced with contextual problems related to daily life, so students are interested in solving them. For this reason, learning needs to provide a structure to solve the problems given.

In SMA Negeri 1 DolokBatuNanggar, students in class learning are only used to solving routine problems. In addition, in learning in the classroom, teachers still teach using conventional methods and do not use LKPD in teaching and learning. LKPD is a scaffolding that serves to guide students in the learning process and encourage students to become independent learners while collaborating with their group members [11]. To assist students in increasing their representational abilities, teachers should provide problems that are able to challenge contextual students. One of them is by using PISA-based questions in learning. PISA develops mathematical problems that can measure students' ability to use knowledge and understanding of mathematical concepts to solve problems encountered in daily life. The questions given in PISA are presented mostly in the context of real-world situations so that the benefits of mathematics can be felt to solve the problems of daily life [12].

Based on these problems, it is necessary to develop LKPD and PISA-based test instruments in learning to improve students' mathematical representation abilities. Therefore, this study aims to produce LKPD and PISA-based test instruments on the RME model to improve students 'mathematical representation capabilities that are valid, practical, effective and can improve students' mathematical representation abilities.

\section{Method}

This research model was a research development using the Tessmer development model. The place and time of the study were in SMA Negeri 1 Dolok Batu Nanggar, Simalungun, in Academic Year 2019/2020. The subjects of the study were students of class X-Science 3 (36 students) and class X-Science 4 (36 students), totaling 72 students. The stages of developing The Student Worksheet $(L K P D)$ and test instruments in this study could be seen in Figure 1.

To see the validity of Student Worksheet (LKPD) and the developed test instrument, it required an instrument of validation by experts and validation from the results of the instrument test developed using the product-moment correlation formula [14] and measuring its reliability with the alpha formula [15]. To see the practicality of Student Worksheet questionnaire and measured in away.

To see the effectiveness of The Student Worksheet (LKPD) and the developed test instruments, the instruments are needed. In this study, the instruments used were test instruments and student response questionnaires.

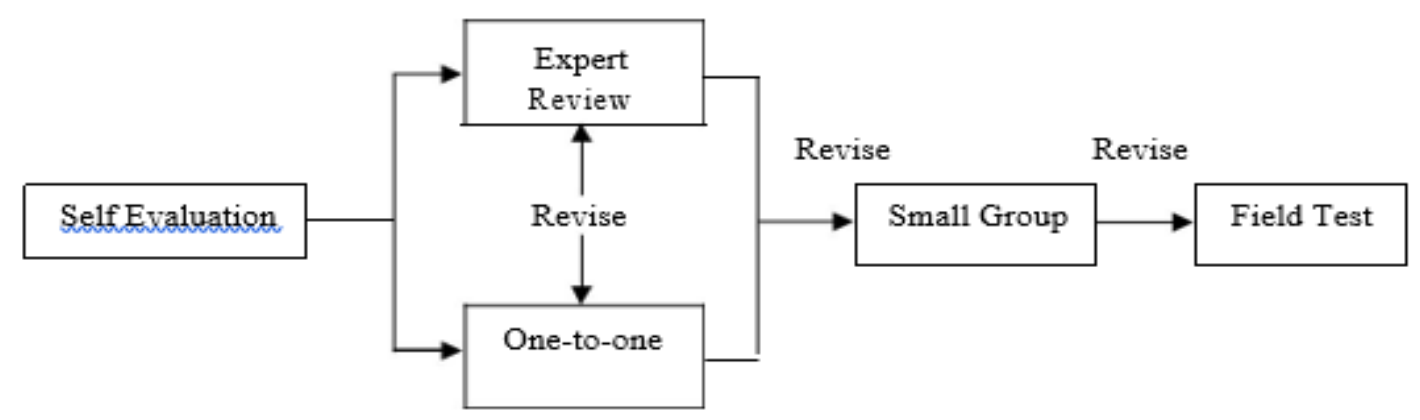

Figure 1. Formative evaluation design flow [13] 
The effectiveness of learning tools developed in terms: 1) completeness of student learning outcomes classically at least $85 \%$; 2) achievement of learning objectives of at least $75 \%$; 3) positive student response of at least $80 \%$; and 4) the achievement of learning time did not exceed the normal learning time [16]. Improvement of students' mathematical representation ability was determined using the N-Gain formula from Hake [17] below. With the gain index criteria as in Table 1:

Table 1. Criteria for Normalized Gain Score

\begin{tabular}{|c|c|}
\hline Gain Score & Interpretation \\
\hline $\mathrm{g}>0,7$ & High \\
\hline $0,3<\mathrm{g} \leq 0,7$ & Medium \\
\hline $\mathrm{g} \leq 0,3$ & Low \\
\hline
\end{tabular}

\section{Results and Discussion}

\subsection{Results}

Description of Development Phase of Learning Materials

The development phase of Student Worksheet (LKPD) and PISA-based test instruments with the Tessmer development model could be described as follows:

1. Perform the Preliminary Stage

The preliminary phase was the stage of determining the place of research subjects and make preparations. The initial stage of this model was to identify learning objectives. Based on the 2013 Curriculum (Kurikulum 2013), mathematics learning aimed to make students have mathematical skills. Mathematical skills were part of the life skills that students must have, especially in the development of reasoning, communication, and problem-solving that were encountered in the daily lives of students.

2. Conducting the Formative Evaluation Stage

- Self-Evaluation

At this stage, a preliminary analysis was conducted: student analysis (analysis of students' knowledge and characteristics), curriculum analysis (analysis of learning objectives, assessment instruments, learning models, learning strategies and analysis of devices or materials to be developed.

- Student Analysis

At this stage, students' knowledge and characteristics were analyzed. Knowledge analysis was carried out to determine the extent of students' mathematical representation abilities. Based on the results of the initial tests of students' mathematical representation abilities, the results obtained that students were not able to associate real problems with mathematical concepts. Then students find it difficult to describe the situation in the problem in the form of a picture that can help him solve the problem. Students also sometimes misunderstand the purpose of the problem. The mathematical representation of students was also incorrect because it lacked the basic concepts of mathematics.

- Curriculum Analysis
In this study, the preparation of teaching strategies as a reference in learning activities was compiled in the form of a Lesson Plan (RPP). At each meeting, the lesson plan was designed by prioritizing the learning objectives, namely improving students' mathematical representation ability. Therefore the problems that were used in the RME approach were problems related to the real situation and presented in every Student Worksheet (LKPD). The compiled lesson plan consisted of 3 (three) sets of 3 (three) meetings with the duration of each meeting is $2 \times 45$ minutes. Lesson Plan (Rencana Pelaksanaan Pembelajaran / RPP) prepared according to the principles and characteristics of the preparation of The Lesson Plan in the 2013 Curriculum.

- Analysis of Materials to be Developed

Learning materials to be developed were problematic learning materials. Learning materials were considered to be a problem because they did not yet exist but did not meet learning needs. Learning materials that developed in this study were Student Worksheet (Lembar Kerja Peserta Didik / LKPD) in Shape and Space content PISA test instruments that aim to improve students' mathematical representation abilities.

3. Development of Student Worksheet (LKPD)

In this study the PISA-Student Worksheet (LKPD) model was developed that can be used as scaffolding in the learning process with the RME model, there was guidance to students in solving the given problems. The developed Student Worksheet (LKPD) consisted of 3 sets for 3 meetings.

4. Development of Test Instruments

The test instrument developed in this study was a matter of pre-test and post-test given to students. Pre-test questions consisted of 4 questions, while post-test questions consisted of 6 questions. The test instrument was developed based on indicators of students' mathematical representation ability and was representative of the learning objectives carried out in the classroom and adapted from PISA questions on shape and space content.

\section{a. Expert Review}

In the evaluation stage, the learning tools and research instruments were validated by experts in their fields and practitioners. The experts in this matter referred to mathematics education lecturers and practitioners in UNIMED also mathematics teachers. In general, expert validation included content validation which contains observation items related: (1) format, (2) language, and (3) content. The results of expert validation were validation scores, corrections, criticisms, and suggestions that were used as a basis for revising and refining the learning tools developed.

Theaverage total results of the Student Worksheet (Lembar Kerja Peserta Didik / LKPD) validation by the expert team was 4.38 (Valid Categories) while the results of the content validation of the test instruments were included in the valid category, the assessment of language and writing questions with categories could be understood, as well as the evaluation of recommendations by small revisions. The results of the revised device developed at this stage were prototype I. 


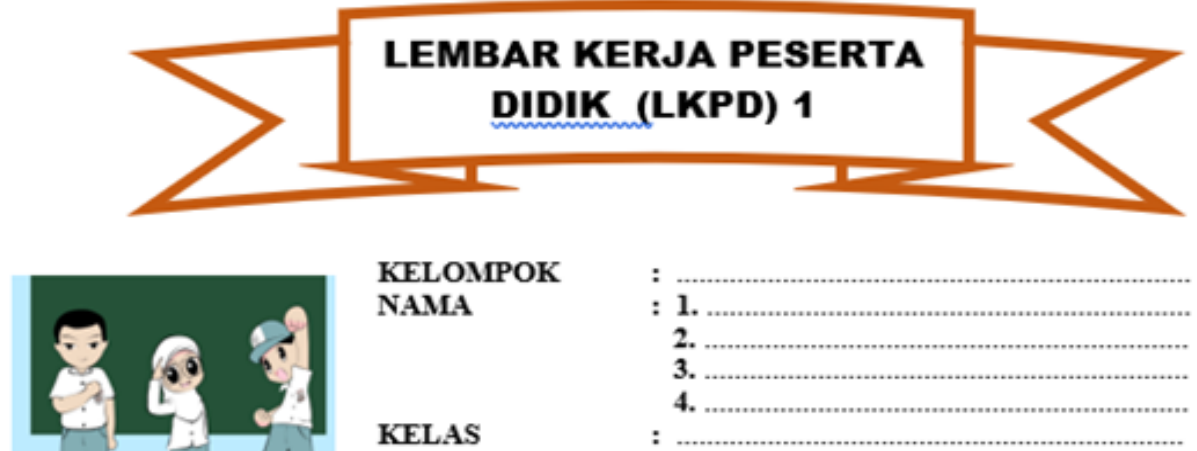

\section{Petuniuk:}

Tujuan yang akan kalian sapai:

1. Siswa mampu mengubah satuan sudut dari derajat ke radian dan putaran.

2. Siswa mampy memahami konsep Berbandingan. trigenometri dalam segitiga siku - sikn.
1. Bacalah LKPD berikut dengan cermat

2. Diskusikan dengan teman sekelompokmu dalam menentukan jawaban yang paling benar

3. Yakinkan bahwa setiap anggota sekelompok mengetahui jawabanya

4. Jika dalam kelompokmu mengalami kesulitan dalam mempelajari LKPD, tanyakan pada gurumu dengan tetap berusaha secara maksimal terlebih dahulu

5. Coba pikirkanlah masalah dibawah ini

secara individu (tuliskan apa yang kamu ketahui dan tidak kamu ketahui di kertas lain yang telah disediakan / membuat catatan kecil)

Figure 2. Front view of Student Worksheet

\section{GARASI RUMAH}

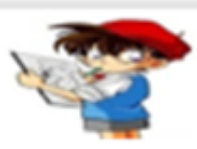

Pak Sabas ingin membeli sebuah mobil bard. Namoun, ijka ingin mobilnya nanti terlindungi dari panas matahari dan bujan, Pak Sabar barus membangun garasinxa terlebib dahulu. Rak Sabar ingin membangun garasi rumak yang memiliki sebuah jendela seperti zambar di bawabh ini.

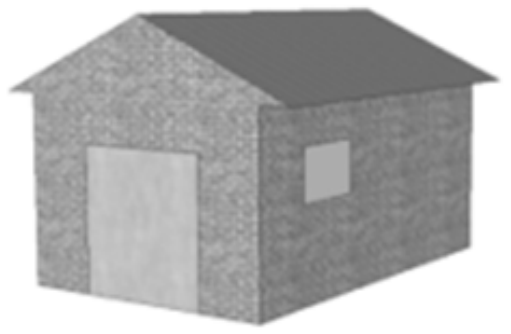

a. Pilihlah gambar di bawah ini yang benar jika Pak Sabar melihat garasi dari sisi belakang?

A

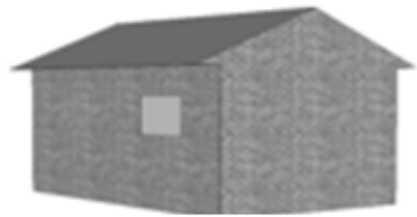

B

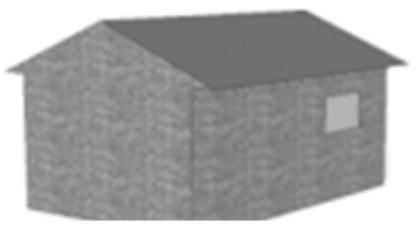


2. PASAR MALAM

(Medlifikasi teral PISA 2012 "Fern's Wheel")

Malam minggu kemarin Doni Bersama teman - temannxa Andi, Rika dan Cantika pergi berialan - jalan ke pasar malam yang ada di daerah pancing, MMTC. Ternxata banyak selkali wahana yang darat dicsba seperti ada wahana tong setan bianglala (baling - baling), kora - kora, dan berbagai permainan lainnxa.

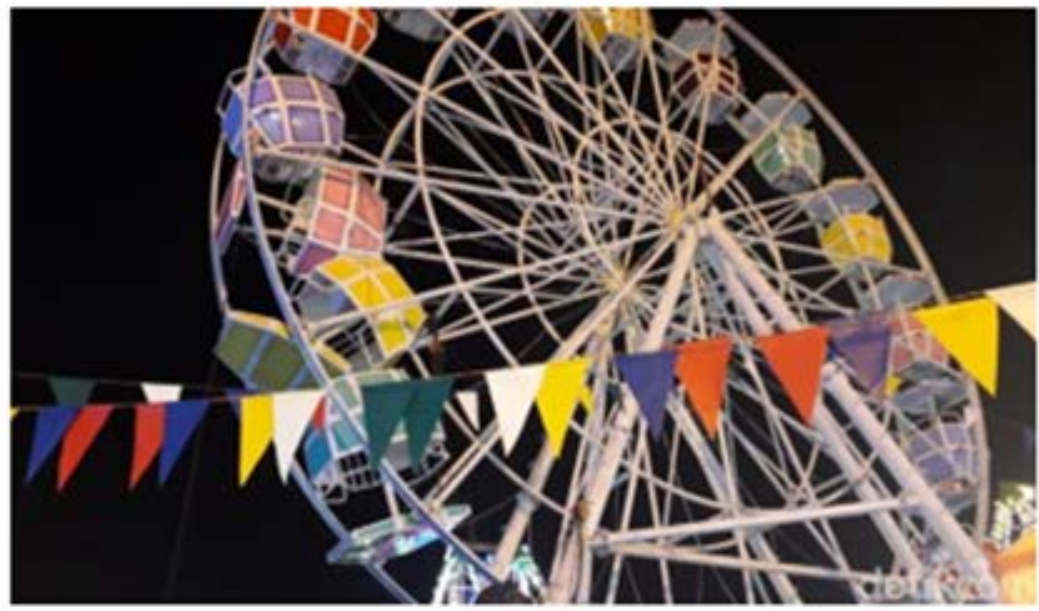

Gambar 1.3 Bianglala.MMTC

Cantika mengaiak mereka semua untuk bermain bianglala Gambar 1.4 merupakan interbretasi dari gambar 1.3. Mereka membeli karcis seharga Rp5000 per orang. Jika ingin menaiki bianglala, mereka harus menaiki tangga selkitar $2 \mathrm{~m}$. Jika titik $P$ menunjukkan posisi awal jika ingin menaiki bianglala, dan PQRS menunjukkan

Figure 4. Visual Display of Developed Test Instrument

\section{b. One to One Test}

In the one-to-one stage, knowing whether the test instrument that has been prepared, could be understood by students, did not cause ambiguity / multiple meanings and could understand the purpose of the problem correctly. One to one test carried out design trials that have been developed for students/teachers who become participants. Researchers chose students from grade XI - Science 1 with the category of high, medium and low ability students. From the analysis of the test results provided it could be concluded that the developed test instruments were included in the valid and reliable categories. For the reliability of the questions obtained the reliability value was $r 11=0.9801$ with a very high category. The results of improvements from this test were carried out, revised and produced prototype II test instruments.

c. Small-Group Test

The results of the improvement of prototype II were tested again in the small group class. This test consisted of 2 students in each group from high, medium and low categories so that the number of students who join the small group was 6 students. Given the revised test instrument on prototype II, there were some questions that were not understood by students or whether there were questions that have multiple meanings, etc. The results of the implementation of this trial were then used for revision before testing in the field trial phase (field test). The results of the analysis of the students' answer process showed that the test instrument was included in the valid category with the reliability of the questions obtained by the reliability value of $\mathrm{r} 11=0.7801$ with the high category. The trial results showed several improvements to the instrument. After a revision of the questions based on students' suggestions /comments on the small group test, the results of the analysis of these items were obtained which was then called prototype III.

d. Field Test

Researchers conducted field trials to determine the validity of the instruments developed, the practicality of the instruments developed, the effectiveness of the instruments developed as well as how to improve students' mathematical representation abilities. In this study, researchers conducted learning activities in 2 different classes, namely X-IPA 3 (Trial I) and X-IPA 4 (Trial II). 


\subsubsection{Test Analysis Results I}

1. The validity of the Instrument Test in Trial I

The test instrument was in a valid category.

Table 2. The Validity of Test Item I

\begin{tabular}{|c|c|c|c|c|}
\hline Questions & $\boldsymbol{r}_{\boldsymbol{x y}}$ & $\boldsymbol{t}_{\boldsymbol{h i t u n g}}$ & $\boldsymbol{t}_{\text {tabel }}$ & Interpretation \\
\hline 1. & 0,6141 & 4,5370 & 2,0420 & Valid \\
\hline 2. & 0,6339 & 4,7797 & 2,0420 & Valid \\
\hline 3. & 0,6983 & 5,6888 & 2,0420 & Valid \\
\hline 4. & 0,6605 & 5,1291 & 2,0420 & Valid \\
\hline 5. & 0,7481 & 6,5727 & 2,0420 & Valid \\
\hline 6. & 0,6012 & 4,3868 & 2,0420 & Valid \\
\hline
\end{tabular}

Based on the first trial, it was found that all items about the mathematical representation ability of students were declared valid with a reliability value of $\mathrm{r} 11=0.7337$ with a high category.

2. The practicality of the instruments developed by Trial I

From the results of the practicality questionnaire analysis on the first try, it was known that many students stated that the tools developed were Student Worksheet (Lembar
Kerja Peserta Didik / LKPD) and PISA test-based test instruments on the Shape and Space content to be able to improve students' mathematical representation ability by $65.5 \%$ (the category was quite practical).

3. Effectiveness of Instruments in Trial I

a. Classical Completeness of Trial I

Based on the effectiveness criteria, classical completeness, from Figure 5, it can be seen that the students that have completed were 15 students or $41.66 \%$. Based on the effectiveness criteria, classical completeness, meaning that the results of the classical completeness test of students in the trial I have not met the effective criteria.

b. Positive Student Response $\geq 80 \%$

Based on the questionnaire given, the average percentage of total positive responses of students in the first trial of $80.56 \%$ can be concluded that the students' responses to the components and learning activities were positive.

c. Achievement of Learning Objectives above $75 \%$

From the picture above it can be seen that the achievement of learning objectives in the trial, I have not been achieved for all items.

\section{Percentage of Classical Completeness on Trial I}

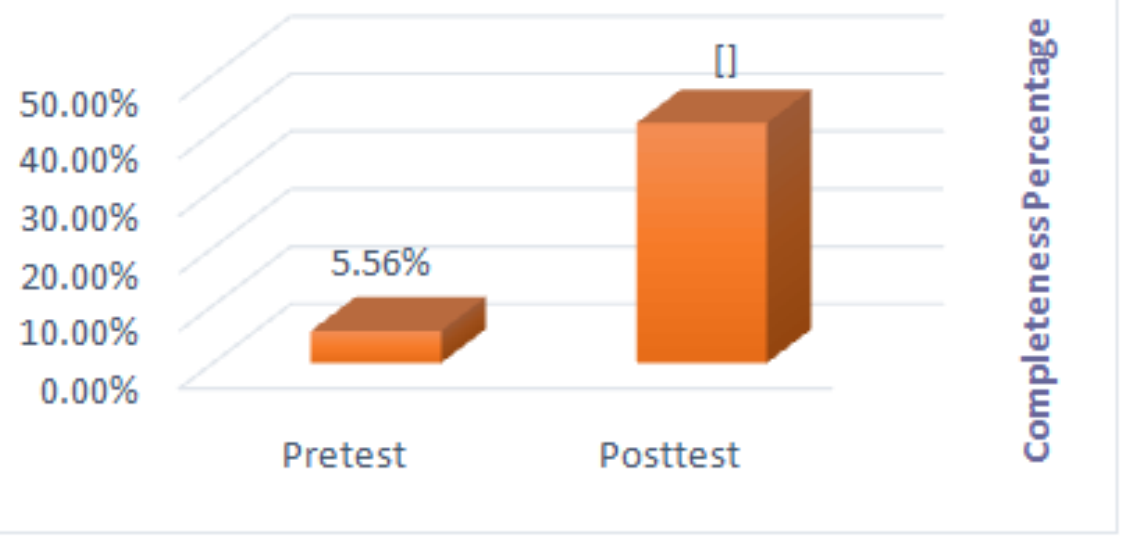

Figure 5. Classical Completeness Test I

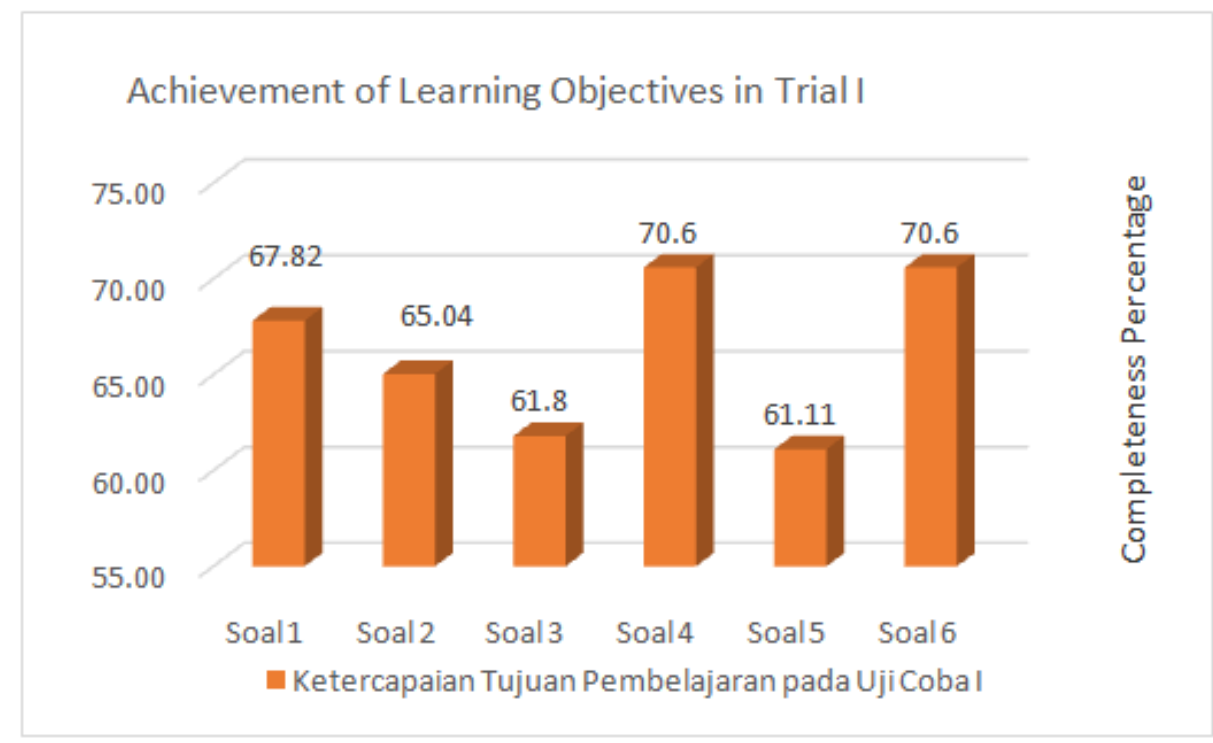

Figure 6. Achievement of Learning Objectives 


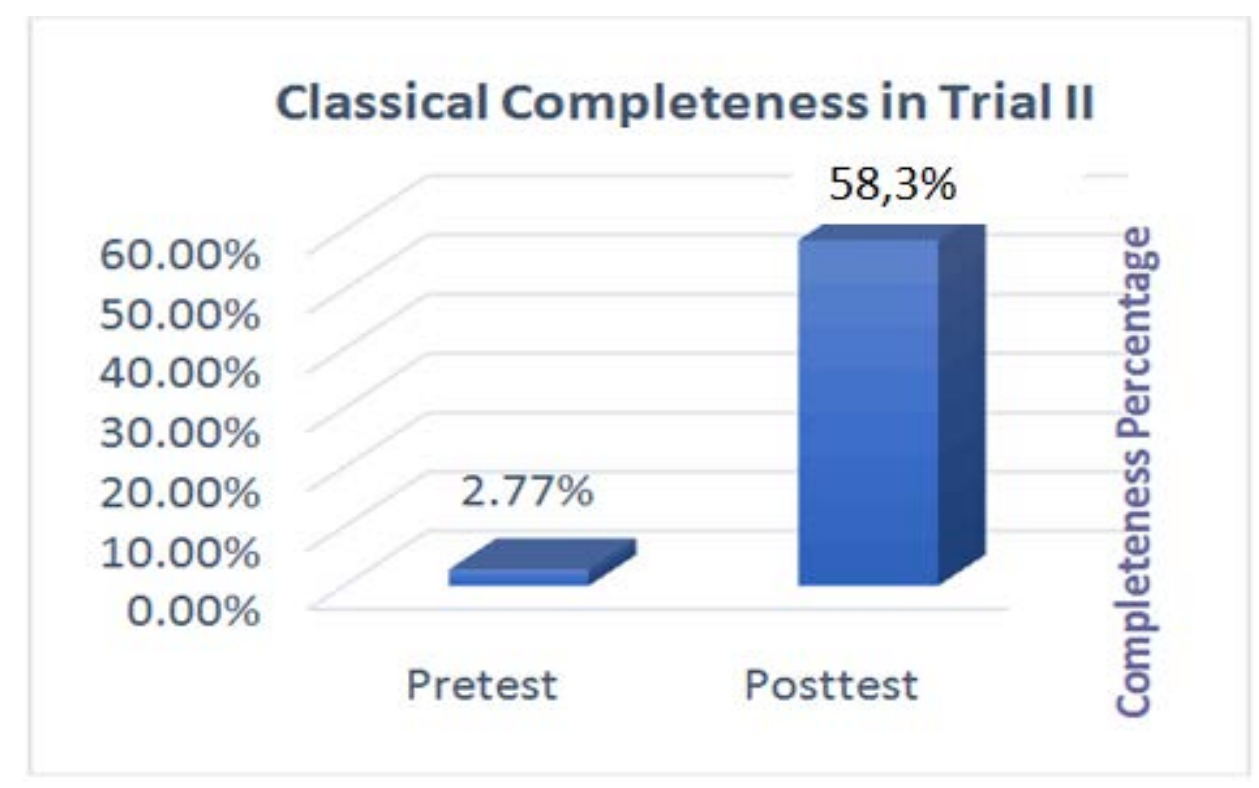

Figure 7. Classical Completeness Test II

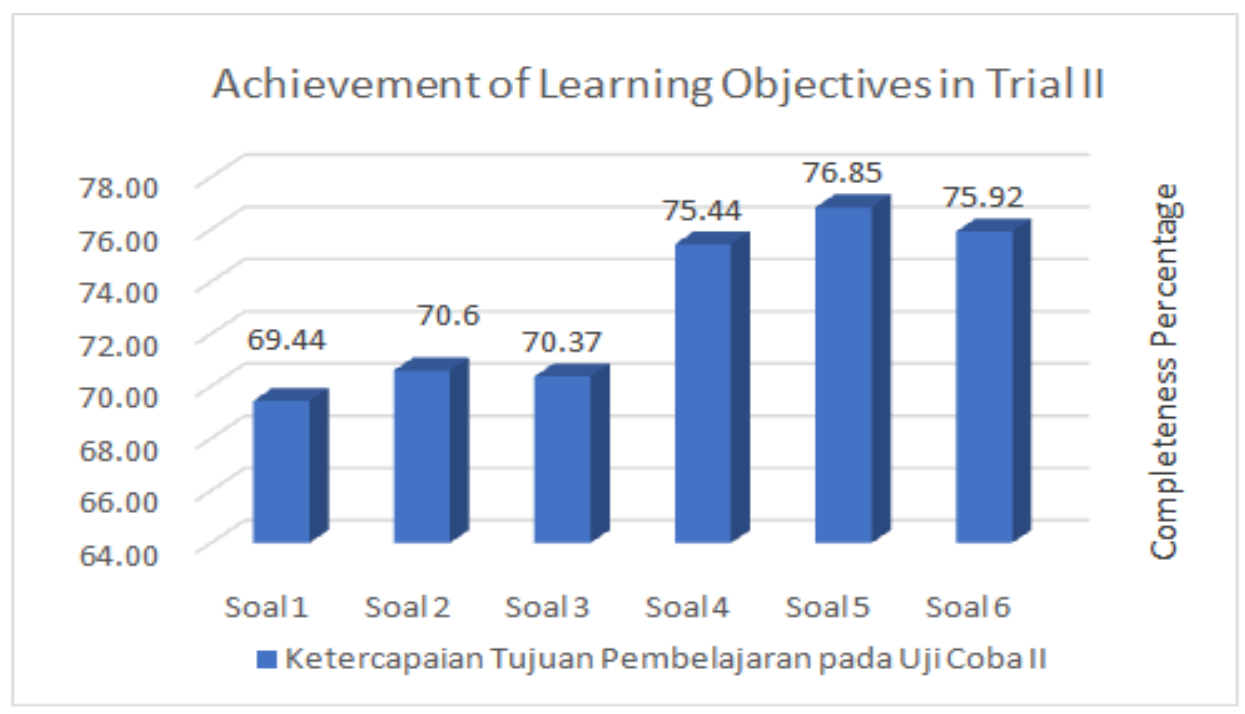

Figure 8. Achievement of Learning Objectives

\section{d. Learning Time}

The results of achieving learning time in Trial I were three meetings or $6 \times 45$ minutes. There was no difference between learning time using Student Worksheet (LKPD) and PISA-based test instruments on the RME model and achieving normal learning time. Thus the achievement of learning time in the trial I have been achieved.

\subsubsection{Analysis Results of Trial II}

1. The Validity of Test Instruments in Trial II. The test instrument was in a valid category.

Table 3. Validity of Test Item II

\begin{tabular}{|c|c|c|c|c|}
\hline Questions & $\boldsymbol{r}_{\boldsymbol{x y}}$ & $\boldsymbol{t}_{\text {hitung }}$ & $\boldsymbol{t}_{\text {tabel }}$ & Interpretation \\
\hline 1. & 0,6141 & 4,5370 & 2,0420 & Valid \\
\hline 2. & 0,6339 & 4,7797 & 2,0420 & Valid \\
\hline 3. & 0,6983 & 5,6888 & 2,0420 & Valid \\
\hline 4. & 0,6605 & 5,1291 & 2,0420 & Valid \\
\hline 5. & 0,7481 & 6,5727 & 2,0420 & Valid \\
\hline 6. & 0,6012 & 4,3868 & 2,0420 & Valid \\
\hline
\end{tabular}

Based on the second trial it was found that all items about the mathematical representation ability of students were declared valid with a reliability value of $\mathrm{r} 11=$ 0.7338 with a high category.

2. The practicality of the instrument developed in Trial II

From the results of the practicality questionnaire analysis in trial II, it was known that many students stated that the materials developed was Student Worksheet (Lembar Kerja Peserta Didik / LKPD) and PISA test-based test instruments on the Shape and Space content to be able to improve students' mathematical representation ability by $79.16 \%$ (practical category).

3. Effectiveness of Instruments in Trial II

a. Classical Completeness of Trial II

Based on effectiveness criteria, classical completeness, from Figure 7, it can be seen that students have completed were 21 students or $58.3 \%$. Based on the effectiveness criteria, classical completeness, meaning that the results of the classical completeness test of students in the trial I have not met the effective criteria. 


\section{b. Positive Student Response}

Based on the questionnaire given, the average percentage of total positive responses of students in Trial II was $92.67 \%$, it can be concluded that students' responses to the components and learning activities were positive.

c. Achievement of Learning Objectives

In Figure 8, it can be seen that the achievement of learning objectives in question number 4 was $75.44 \%$, problem number 5 was $76.85 \%$ and problem number 6 was $75.92 \%$. As for questions number 1,2 and 3 the learning objectives have not yet been reached. Thus the achievement of learning objectives in trial II has not been achieved for all items.

d. Learning Time

The results of achieving learning time in Trial II were three meetings or $6 \times 45$ minutes. There was no difference between learning time using Student Worksheet (Lembar Kerja Peserta Didik / LKPD) and PISA-based test instruments on the RME model and achieving normal learning time. Thus the achievement of learning time in Trial II has been achieved.

4. Improvement of Students' Mathematical Representation Ability

After learning by using the RME model, giving Student Worksheet (Lembar Kerja Peserta Didik / LKPD) as scaffolding, from the results of the pre-test and post-test mathematical representation ability there was an increase in students' mathematical representation ability. In Trial I, the average $\mathrm{N}$-gain score was 0.4 (medium criteria), whereas, in Trial II, the average N-gain score was 0.6 (medium category).

\subsection{Discussion}

Based on the results of the post-test analysis of trial I and trial II it was found that student learning outcomes met the classical completeness criteria. This was seen from the results of tests of students' mathematical problem-solving abilities where less than $85 \%$ of students get a score of $\geq 70$ with a complete category.

The used of Student Worksheet (Lembar Kerja Peserta Didik / LKPD) in learning RME was able to guide students to build their own knowledge. The use of the PISA-based Student Worksheet (Lembar Kerja Peserta Didik / LKPD) on the RME model provides instructions that guide students towards the right completion so that student learning outcomes improve. This was consistent with research conducted [18] which states that the use of worksheets was able to facilitate students in learning and improve student learning outcomes. In addition, with the title "Effectiveness Worksheet with Problem Solving Approach" concludes that learning using worksheets through problem-solving approaches was able to facilitate the increase in students' potential in learning [19].

In the RME model students are challenged to solve a problem that had never been encountered before. Therefore students were trained to be able to associate the knowledge they already have with new problems encountered. Although RME was a learning model that directs students to learn actively and independently, RME was not a learning model without guidance at all. As expressed by Hmelo, Duncan \& Chin stated that problem-based learning was not a learning approach with minimal guidance, but rather provides scaffolding and guidance to facilitate learning by students.

The availability of LKPD in learning with the RME model as scaffolding in this study helps students solve the problems given and was effective for classes with large numbers of students. This was consistent with what was expressed by [20] that the use of worksheets in the RME model with class characteristics with a large number of students and low-level thinking skills is very effective.

The use of PISA problems in contexts that are close to student life increases student motivation in solving given problems. This was in line with what was expressed by Charmila, Zulkardi, and Darmawijoyo [21] who stated that learning to use context makes students find meaningful relationships between abstract ideas and practical applications in real-world contexts. In addition, the use of local contexts can help students understand mathematical phenomena from the perspective of their own life experiences. This makes mathematics much more interesting and useful for all students.

The criteria for mathematical problems in PISA were arranged to see a person's ability to formulate, apply, and interpret mathematics in a variety of contexts that were very suitable for measuring the ability of problem-solving. Therefore, the use of PISA-based problems in problem-based learning was considered as something appropriate to improve student'sproblem-solving abilities and students' mathematical representations.

Positive responses were given by students to the use of Student Worksheet (Lembar Kerja Peserta Didik $/ L K P D)$ and PISA-based test instruments in learning because students felt helped by the existence of Student Worksheet (Lembar Kerja Peserta Didik / LKPD) in learning. In addition, the problems presented were problems with contexts that are close to student life. So students were interested and feel challenged in completing it. This was supported by previous research by Naimah [22] which states that students' responses to the use of Student Worksheet (Lembar Kerja Peserta Didik /LKPD) in RME are on average good. Students considered that the use of Student Worksheet (Lembar Kerja Peserta Didik / LKPD) in problem-based learning was new and interesting.

\section{Conclusion}

Based on the results of the analysis and discussion in this study, the following conclusions were presented:

a) PISA-based Student Worksheet (Lembar Kerja Peserta Didik / LKPD) on shape and space content in he developed RME model had met the criteria of validity and practicality, but had not yet met the effectiveness in terms: a) Classical student completeness had reached $55.8 \%$ in the second trial and had not met the achievement criteria classical completeness; b) Achievement of learning objectives $\geq 75 \%$ seen from the answers of students in the post-test questions number 4.5 and 6 ; c) students gave positive responses to Student Worksheet (Lembar Kerja Peserta Didik / LKPD) and the test instruments used; and d) The learning time using the PISA-based Student Worksheet (Lembar Kerja Peserta 
Didik / LKPD) on the RME model was the same as the normal learning time.

b) Students' mathematical representation ability was improved after learning by using the Student Worksheet (Lembar Kerja Peserta Didik / LKPD) and PISA-based test instruments on the RME model seen from the results of the pre-test - post-test in trial I with an N-Gain score of 0.4 (medium category) and the trial II the average pre-test - post-test result based on N-Gain calculations got a score of 0.6 in the medium category.

\section{Acknowledgments}

On this occasion, the authors would like to express their sincere thanks and highest appreciation to all those who have helped the authors: Dr. KMS. M. Amin Fauzi, M.Pd as the first supervisor, Dr. Izwita Dewi as my second supervisor and Chairman of the Mathematics Education Postgraduate Study Program, Prof. Dr. Edi Syahputra, M.Pd, and Karnali Saragih, M.Pd , as the Principal of SMA Negeri 1 Dolok Batu Nanggar, who has given permission and the opportunity for the writer to conduct a research the school, as well as the teachers and administrative staff who have helped many writers in conducting this research.

\section{Reference}

[1] Novita, R \& Niawati. 2016. The Application of Contextual Approach in Geometry Cubes and Blocks in $8^{\text {th }}$ Grade Junior High School. Numeracy. Volume 3 No 1 pp 36-49.

[2] Dewimarni, Syelfia. 2017. Analysis of Communication Skills and Understanding of Linear Algebra Concept for Students in Universitas Putra Indonesia 'YPTK' Padang. Mathematics Education Journal. Vol 8 No 1, 2017, pp 53-62.

[3] NCTM. 1999. Mathematics Teacher. Volume 92 No. 1

[4] Dwiyogo, Wasis. 2016. Teaching and Learning Process: Thinking and Problem Solving. The Online Journal of New Horizons in Education Volume 6, Pg 121-129.

[5] OECD, PISA. 2017. How Does PISA for Development measure mathematical literacy? Paris: OECD Publisher.

[6] OECD. 2013. The PISA 2003 Assessment Framework: Mathematics, Reading, Science, and Problem Solving Knowledge Skills. Paris: Author, 2013.
[7] Hasan, Buaddin. 2015. The Use of Scaffolding to Overcome Difficulties in Solving Mathematical Problems. Journal of Mathematics Study Program. Vol 1 No 1.

[8] Choo, Serene. 2017. Effect of worksheet scaffolds on student learning in problem-based learning. Advances in Health Sciences Education

[9] Verenikina, Irina. 2008. Scaffolding and Learning: It's role in Nurturing New Learners. Univesity of Wollongong Research Online

[10] Minarni, Ani. 2016. Mathematical Understanding And Representation Ability Of Public Junior High School In North Sumatra. Journal on Mathematics Education. Volume 7, No 1, pp 43-56.

[11] Hmelo-Silver, C. E, Duncan, R. G, and Chin, C. A. 2006 "Scaffolding and Achievement in Problem-Based and Inquiry Learning: A Response to Kirschner, Sweller, and Clark” Journal of Educational Psychologist, 42 (2), 99-107.

[12] Kamaliyah, Zulkardi. 2013. Developing the Sixth Level of PISALike Mathematics Problems for Secondary School Students. Journal Mathematics Education. Vol. 4 No. 1 January 2013, pp. 9-28

[13] Tessmer, Martin. 1993. Planning and Conducting Formative Evaluations. Philadephia: Kogan.

[14] Sugiyono. 2011. Quantitative, Qualitative, and R\&D Research Methods. Bandung.

[15] Arikunto, S. 2013. Research Procedure: A Practical Approach. Jakarta: Rineka Cipta.

[16] Kurniati, Intan. 2018. The Development of Student Worksheet Based on PISA to Improve Problem Solving Ability. American Journal of Educational Research. 2018, 6(11), 1581-1585.

[17] Hake, RR. 1998. "Interactive-Engagement Versus Traditional Methods: A Six-Thousand-Student Survey of Mechanics Data Test for Introductory Physics Courses," American Journal of Physics, 66 (1).

[18] Barniol, P and Zavala, G. 2016. "A Tutorial Worksheet to Help Students Develop the Ability to Interpret the Dot Product as a Projection," Eurasian Journal of Mathematics, Science \& Technology Education, 12 (9). 2387-2398.

[19] Askois, A \& Jailani. 2017."Effectiveness of Worksheet with Problem Solving Approach," Proceeding: International Seminar on Innovation in Mathematics and Mathematics

[20] Haruehansawasin, S and Kiattikomol, P, "Scaffolding in Problem Based Learning for Low-Achieving Learners," The Journal of Educational Research.

[21] Charmila, Ninik. 2016. PISA Model Mathematics Development Using the Jambi Context. Journal of Educational Research \& Evaluation. Volume 20, No. 2, Dec 2016 (198-207).

[22] Naimah, K.2016. Effectiveness of Solution-Based Mathematics Worksheets Problems, Muhammadiyah University Surakarta, Surakarta.

(C) The Author(s) 2019. This article is an open access article distributed under the terms and conditions of the Creative Commons Attribution (CC BY) license (http://creativecommons.org/licenses/by/4.0/). 